\title{
ACTUAL PROBLEMS OF PSYCHOLOGICAL SUPPORT OF HEALTHCARE WORKERS IN INFECTIOUS HOSPITALS FOR PATIENTS WITH COVID-19 IN THE TERRITORY OF THE KRASNOYARSK REGION
}

Sevostyanova MS', Selezneva NV', Chernomurova PA'1, Kharchenko ZS'1, Glushkova KV², Fetisov AO'1, Sapova AV², Semichev EV²

${ }^{1}$ Federal State-Financed Institution Federal Siberian Research Clinical Centre, Federal Medical Biological Agency of Russia, Krasnoyarsk, Russia

2 Clinical Hospital № 42, Zelenogorsk, Russia

\begin{abstract}
Annotation. This article presents the experience of implementing psychological support measures for healthcare workers of infectious hospitals for patients with COVID-19 during a pandemic. The results of an empirical study of the prevalence, severity and specificity of the development of anxiety and depressive symptoms in healthcare workers of residents of a megalopolis (Krasnoyarsk), a closed territorial district (Zelenogorsk) and seconded to the North Yenisei district of the Krasnoyarsk Territory depending on social status and professional factors of burnout are presented. The stages of the implementation of measures of psychological support for the activities of healthcare workers are described. A comparative analysis of the involvement of employees of various infectious hospitals was carried out. Material and methods. The total sample of the study included 126 subjects (21 men and 105 women) engaged in the provision of medical care in three infectious diseases hospitals for patients with COVID-19 in the Krasnoyarsk region. To achieve the goals and objectives of the study, the following methods were used: psychodiagnostic testing with the BDI scale, STAI test and MBI questionnaire, and statistical data processing (Spearman rank correlation coefficient, Mann-Whitney-Wilcoxon U-test). We invited 284 medical workers to participate in psychological support activities. Results and conclusions. The prevalence of subdepression among medical personnel varies from 5.5 to $30.9 \%$, depending on the location of the infectious diseases hospital for patients with COVID-19. Severe depressive symptoms were detected in $4.46 \%$ of the total number of subjects. A low level of situational anxiety was detected in less than $30 \%$. It has been confirmed that employees of a younger age and with less experience are more susceptible to the development of depersonalization and cognitive-affective symptoms of depression. And employees who do not have children show higher indicators of situational and personal anxiety. Moreover, despite the prevalence of alarming and depressive symptoms, there is a low involvement and unwillingness of healthcare workers to participate in psychological support activities.
\end{abstract}

Keywords: anxiety, depression, COVID-19, psychological support, burnout, occupational stress

Received: 25.06.2020 Accepted: 17.07.2020 Published online: 06.08.2020

DOI: 10.47183/mes.2020.005

\section{АКТУАЛЬНЫЕ ПРОБЛЕМЫ РЕАЛИЗАЦИИ МЕРОПРИЯТИЙ ПСИХОЛОГИЧЕСКОГО ОБЕСПЕЧЕНИЯ ДЕЯТЕЛЬНОСТИ МЕДИЦИНСКИХ РАБОТНИКОВ ИНФЕКЦИОННЫХ ГОСПИТАЛЕЙ ДЛЯ ПАЦИЕНТОВ C COVID-19 НА ТЕРРИТОРИИ КРАСНОЯРСКОГО КРАЯ}

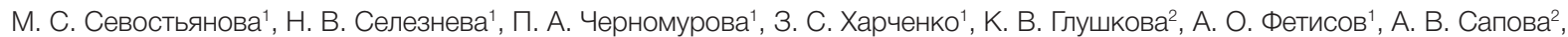
Е. В. Семичев²

Федеральное государственное бюджетное учреждение «Федеральный Сибирский научно-клинический центр» Федерального медико-биологического агентства, Красноярск, Россия

Клиническая больница № 42, Зеленогорск, Россия

\begin{abstract}
Аннотация. В статье обобщен опыт проведения мероприятий психологического сопровождения медицинских работников инсекционных госпиталей для пациентов с COVID-19 в период пандемии. Представлены результаты эмпирического исследования распространенности, выраженности и специсики развития тревожной и депрессивной симптоматики у медицинских работников - жителей мегаполиса (г. Красноярск), ЗАТО (г. Зеленогорск) и командированных в Северо-Енисейский район Красноярского края в зависимости от социального статуса и факторов профессионального выгорания. Описаны этапы реализации мероприятий психологического обеспечения деятельности медицинских работников, проведен сравнительный анализ вовлеченности сотрудников различных инфекционных госпиталей. Материал и методы. Общая выборка исследования представлена 126 испытуемыми (21 мужчина и 105 женщин), занятых оказанием медицинской помощи в трех инфекционных госпиталях для пациентов с COVID-19 на территории Красноярского края. Для реализации целей и задач исследования применялись методы анкетирования, психодиагностического тестирования (Шкала депрессии Бека (BDI), тест Спилбергера (STAI), опросник выгорания для медицинских работников Маслач (MBI) и статистической обработки данных (коэффициент корреляции рангов Ч. Спирмена, U-критерий Манна-Уитни-Уилкоксона). К участию в мероприятиях психологического обеспечения были приглашены 284 сотрудника. Результаты и выводы. Распространенность субдепрессии у медицинского персонала варьируется от 5,5 до 30,9\% в зависимости от месторасположения инфекционного госпиталя. Выраженная депрессивная симптоматика выявлена у 4,46\% от общего числа испытуемых. Низкий уровень ситуативной тревожности выявлен менее чем у 30\%. Подтверждено, что сотрудники более младшего возраста и с меньшим трудовым стажем в большей степени подвержены развитию деперсонализации и когнитивно-аффективной симптоматики депрессии. А сотрудники, не имеющие детей, демонстрируют более высокие показатели ситуативной и личностной тревожности. При этом, несмотря на распространенность тревожной и депрессивной симптоматики, отмечается низкая вовлеченность и неготовность медицинских работников участвовать в мероприятиях психологического сопровождения.
\end{abstract}

Ключевые слова: депрессия, COVID-19, психологическое сопровождение, тревожность, профессиональное выгорание, производственный стресс

Статья получена: 25.06.2020 Статья принята к печати: 17.07.2020 Опубликована онлайн: 06.08.2020

DOI: $10.47183 /$ mes.2020.005

The theme of psychological support for healthcare workers is particularly relevant during the COVID-19 pandemic. Numerous studies reported by domestic and foreign authors demonstrate the negative impact of various viral infections spread in epidemic and pandemic amounts both on the physical and psychological well-being of the population $[4,5,6,8,9,10,13]$. The risk of negative mental and emotional state in medical specialists working in direct contact with infected patients is emphasized
$[4,5,6]$. The recent reports published by foreign colleagues from Italy and China summarize the results confirming the prevalence of depression (50.3\%), anxiety (44.6\%) and insomnia (34\%) in healthcare workers during the COVID-19 pandemic. Concerns about the adverse psychological effects revealed are compounded by the high rate of pre-existing psychological problems, as well as by the high total suicide rate among physicians. The Chinese and Italian researchers also 
point out that the long ignored, untreated depression together with difficult working conditions can be a deadly combination [4]. Another large-scale study performed by Chinese scientists revealed some psychological disorders in $39.1 \%$ of healthcare workers. For example, the psychological distress in specialists working in Wuhan was related to the risk of infection and insufficient protective measures [10]. Professor Neil Greenberg, psychiatrist from King's College London, expert in the field of diagnosis and treatment of psychological trauma, occupational stress, mental and post-traumatic stress disorders, and his team introduced the "moral injury" concept explaining the typical mental health problems the healthcare workers face during the pandemic [12]. The Chinese researchers determined that close contact of medical staff with COVID-19 patients combined with spending 2 hours and above daily on the news led to worsening of the anxiety and depression symptoms. However, the use of online platforms as an instrument of psychological support reduced the impact of discussed factors [13].

In Russia serious steps had been undertaken towards maintaining the healthcare workers' psychological wellbeing during the pandemic. Veronika I. Skvortsova, Head of the Federal Medical-Biological Agency, reported the need to establish a psychological support service in the federal medical centers transformed into hospitals for patients with COVID-19. The Federal Medical-Biological Agency (Federal Brain and Neurotechnologies Center) together with the team of the Faculty of Psychology of Lomonosov Moscow State University and the psychological service of the Armed Forces of the Russian Federation issued guidelines on the psychological support of healthcare institutions heads and heads of departments in the context of care provision to COVID-19 patients, guidelines on prevention of psychological ill-being in physicians and healthcare workers during the pandemic, and guidelines on the target groups psychological support in medical institutions during the COVID-19 pandemic [3].

The study was aimed to analyze the experience of psychological support provision to the healthcare specialists working in the infectious diseases hospitals during the novel coronavirus infection (COVID-19) pandemic caused by SARS-CoV-2. One of the key research tasks was to study the anxiety and depression signs development in medical professionals engaged in care provision to COVID-19 patients in the Krasnoyarsk Territory in relation to various social and psychological factors (age, marital status, etc.), including the occupational burnout severity, in order to customize the psychological support strategy for healthcare workers during the pandemic.

The levels of state and trait anxiety, depression and occupational burnout in healthcare workers were studied as a part of the study. It should be noted that state anxiety is the emotional state related to current situation of testing. The trait anxiety is the individual's stable tendency to experience anxiety across many situations [2]. Occupational (emotional) burnout includes the following factors: emotional exhaustion, depersonalization, and reduced personal accomplishment. Emotional exhaustion is characterized by the emotional fatigue, emotional resources overextension and indifference. Depersonalization is a combination of various impaired relationships with others. Reduced personal accomplishment is distinguished by the tendency to negative self-appraisal, limiting of capabilities, decline in the feeling of competence and successful achievement [1]. Depression is considered a combination of cognitive-affective (low mood, pessimism, sense of failure, lack of satisfaction, guilt feelings, sense of punishment, self-dislike, self-accusation, suicidal wishes, crying, irritability, social withdrawal) and somatic symptoms (indecisiveness, distortion of body image, work inhibition, sleep disturbance, fatigability, loss of appetite, weight loss, somatic preoccupation, and loss of libido) [11].

\section{METHODS}

The survey sample included 126 subjects (21 men and 105 women), who provided medical care in the infectious diseases hospitals for COVID-19 patients of the Krasnoyarsk Territory. Of them 23 people were physicians, 55 were mid-level practitioners, and 48 were nursing staff. At the time of the survey all specialists worked in the "red zone" of the hospital (for an average of $10.3 \pm 4.2$ days) in close contact with the patients.

The following methods were used to achieve the goals and objectives of the study: 1) questionnaire survey; 2) psychodiagnostic testing using the Beck Depression Inventory (BDI), State-Trait Anxiety Inventory (STAI) customized by Khanin YuL, Maslach Burnout Inventory (MBI) customized by Vodop'janova NE and Starchenkova ES; 3) statistical analysis (correlation analysis using the Spearman's rank correlation coefficient and the Wilcoxon-Mann-Whitney U-test). The results were processed using the STATGRAPHICS Plus software package.

The study was carried out in three hospitals for patients with coronavirus infection: Federal Siberian Research Clinical Center under FMBA of Russia (hospital № 1), Krashoyarsk, branch of FSRCC FMBA of Russia, Clinical Hospital No. 42 in the closed territorial district Zelenogorsk (hospital No. 2), and in the field hospital deployed in the territory of "Olimpiadinsky" Ore Mining and Processing Enterprise in the Eruda settlement of Severo-Yeniseysky District of the Krasnoyarsk Territory for the Polyus Krasnoyarsk company employees infected with COVID-19 (hospital № 3). Inclusion criteria: submitted informed consent, and a conscious desire to participate in the study (it should be noted that initially 142 healthcare workers were offered to participate in the study, of them 16 people refused (11.2\%)). For general survey sample characteristics see Table 1.

\section{RESULTS AND DISCUSSION}

The prevalence of sub-threshold (mild) depression among the study participants was 5.5-30.9\% depending on the infectious hospital location, the maximum values were observed in specialists sent to Severo-Yeniseysky District (Table 2). Thus, 94.5\% of Zelenogorsk hospital employees had no symptoms of depression, in the Krasnoyarsk and Eruda settlement hospitals the proportions of such workers were $81.1 \%$ and $65.4 \%$ respectively. Symptoms of depression (mild, moderate and severe) were diagnosed in 6 people $(4.76 \%$ of total number of participants). Low levels of state anxiety were revealed in less than $30 \%$ of healthcare workers regardless of the infectious diseases hospital location (Table 2). In most respondents the moderate levels of state anxiety were diagnosed (55.5-61.81\% of surveyed subgroups). The prevalence of high levels of state anxiety was $12.72-16.6 \%$. The moderate level of trait anxiety was detected in more than $70 \%$ of surveyed workers, and the prevalence of high trait anxiety varied significantly (from 11.1\% in Zelenogorsk to $20.75 \%$ in Krasnoyarsk).

Some differences in the degree of healthcare workers occupational burnout factors were observed depending on the infectious hospital location. High levels of emotional exhaustion were detected in 11.3\% of employees in the Krasnoyarsk hospital for patients with COVID-19 (by comparison, in other 
hospital that parameter did not exceed 5.5\%). At the same time, more than $20 \%$ of the infectious diseases hospitals № 1 and 3 employees had high levels of depersonalization (in Zelenogorsk there were $5.5 \%$ of such workers). Almost $45 \%$ of the hospital № 2 healthcare workers were diagnosed with high levels of reduced personal accomplishment, while in other hospitals the proportion of employees with high reduced personal accomplishment did not exceed 30\% (Table 2).

The average scores for cognitive-affective (subscale C-A) and somatic (subscale S-P) symptoms of depression, anxiety and occupational burnout in physicians of infectious diseases hospitals for patients with COVID-19 are listed in Table 3. It is important to understand that when interpreting data using the "reduced personal accomplishment" scale, score 33 and higher is considered low, and score 22 and lower is considered high.

The relationship between the depression, anxiety and occupational burnout symptoms severity, and the healthcare workers' marital status was analyzed (partnership status (married) was compared with other statuses (divorced, single)). In the hospitals № 1 and 2 no significant correlation between the symptoms severity and the marital status was observed. Meanwhile, the cognitive-affective symptoms severity in married workers seconded to the hospital № 3 located in Eruda settlement of Severo-Yeniseysky District was

Table 1. General characteristics of studied subgroups significantly higher compared to their colleagues with other marital status. It can be concluded that marital status does not influence the anxiety, depression and occupational burnout symptoms in the infectious hospital employees working and living in the same city. Nevertheless, in "family" people working away from their home, being apart from the partner and related emotional experience were more acute, which led to worsening of cognitive-affective symptoms of depression (Table 4).

The relationships between anxiety, depression and occupational burnout levels, and age, professional experience, and number of children in the family revealed in healthcare workers using correlation analysis depended on the infectious diseases hospital location. Thus, negative correlations were observed between age, professional experience, and cognitive-affective symptoms of depression in the hospital No. 2 employees, as well as between the number of children in the family and the state anxiety $(k=-0.513, p \leq 0.05 ; k=$ $-0.685, p \leq 0.01 ; k=-0.577, p \leq 0.05)$. Negative correlations were also observed between age and depersonalization, number of children in the family and trait anxiety in the hospital № 1 employees ( $k=-0.236, p \leq 0.05 ; k=0.320, p \leq 0.05)$. However, the tendencies revealed were not confirmed during the infectious hospital № 3 employees' survey. There were no correlations between age, professional experience and number

\begin{tabular}{|c|c|c|c|c|}
\hline & & Hospital № $1(n=53)$ & Hospital № $2(n=18)$ & Hospital № $3(n=55)$ \\
\hline \multicolumn{2}{|c|}{ Average age of workers (years) } & $39.06 \pm 18.3$ & $44.2 \pm 12.6$ & $38.4 \pm 15.8$ \\
\hline \multicolumn{2}{|c|}{ Professional experience (years) } & $17.3 \pm 12.4$ & $18 \pm 6.5$ & $15.9 \pm 9.1$ \\
\hline \multirow{3}{*}{ Marital status } & Married (\%) & 43.39 & 66.66 & 34.5 \\
\hline & Single (\%) & 37.7 & 33.3 & 36.36 \\
\hline & Divorced (\%) & 18.86 & - & 21.81 \\
\hline \multicolumn{2}{|c|}{ Number of children } & $\begin{array}{l}\text { An average of one child } \\
\text { per family }\end{array}$ & $\begin{array}{l}\text { An average of more than } \\
\text { one child per family }\end{array}$ & $\begin{array}{l}\text { An average of less than } \\
\text { one child per family }\end{array}$ \\
\hline \multicolumn{2}{|c|}{ Proportion of individuals having no children } & 26.4 & 5.55 & 44.6 \\
\hline
\end{tabular}

Table 2. Comparison of state and trait anxiety, depression and occupational burnout levels in employees of infectious diseases hospitals for COVID-19 patients

\begin{tabular}{|c|c|c|c|c|}
\hline & & $\begin{array}{l}\text { Hospital № } 1(n=53) \text {, } \\
\text { Proportion of people, } \%\end{array}$ & $\begin{array}{l}\text { Hospital № } 2(n=18), \\
\text { Proportion of people, \% }\end{array}$ & $\begin{array}{l}\text { Hospital № } 3(n=55) \text {, } \\
\text { Proportion of people, \% }\end{array}$ \\
\hline \multirow{5}{*}{ Depression } & No symptoms & 81.1 & 94.5 & 65.4 \\
\hline & Mild (sub-threshold) & 11.3 & 5.5 & 30.9 \\
\hline & Moderate & 1.88 & 0 & 1.81 \\
\hline & Pronounced & 5.66 & 0 & 0 \\
\hline & Severe & 0 & 0 & 1.81 \\
\hline \multirow{3}{*}{ State anxiety } & Low & 28.3 & 27.7 & 25.45 \\
\hline & Moderate & 56.6 & 55.5 & 61.81 \\
\hline & High & 15.09 & 16.6 & 12.72 \\
\hline \multirow{3}{*}{ Trait anxiety } & Low & 5.66 & 16.6 & 16.36 \\
\hline & Moderate & 73.58 & 72.2 & 72.7 \\
\hline & High & 20.75 & 11.1 & 12.72 \\
\hline \multirow{3}{*}{ Emotional exhaustion } & Low & 49.06 & 55.6 & 58.19 \\
\hline & Moderate & 39.62 & 38.8 & 38.18 \\
\hline & High & 11.32 & 5.5 & 3.63 \\
\hline \multirow{3}{*}{ Depersonalization } & Low & 22.65 & 27.8 & 52.73 \\
\hline & Moderate & 54.71 & 66.6 & 27.27 \\
\hline & High & 22.64 & 5.55 & 20.00 \\
\hline \multirow{3}{*}{ Reduced personal accomplishment } & Low & 33.9 & 5.5 & 49.1 \\
\hline & Moderate & 39.6 & 50 & 23.63 \\
\hline & High & 26.4 & 44.5 & 27.27 \\
\hline
\end{tabular}


of children. Thus, it can be concluded that when working in the infectious diseases hospitals for COVID-19 patients the younger and less experienced employees are more susceptible to depersonalization at work and to cognitive-affective depression symptoms development. Any children in the family and the number of children positively correlate with state and trait anxiety levels: with an increase in the number of children per family, these indicators decrease. According to currently available literary sources taking into account the survey sample sex/age composition this can be explained by the fertile age women's concerns about possible risk of miscarriage and pregnancy complications due to contact with infectious agents and preventive anti-infective medications [7].

The relationship between the anxiety and depression symptoms severity, and the occupational burnout factors, was analyzed (Table 5).

Multiple correlations revealed indicate the relationship between the occupational burnout phenomenon and the current psycho-emotional status of healthcare workers, particularly of those being the inhabitants of metropolises or being sent to

Table 3. Average levels of depression, anxiety and occupational burnout in physicians working in infectious diseases hospitals for COVID-19 patients

\begin{tabular}{|c|c|c|c|c|}
\hline & & Hospital № 1 & Hospital № 2 & Hospital № 3 \\
\hline \multirow{3}{*}{ Depression } & C-A & $3.83 \pm 4.2$ & $2.33 \pm 2.9$ & $3.85 \pm 3.4$ \\
\cline { 2 - 5 } & S-P & $1.92 \pm 1.9$ & $1.16 \pm 1.65$ & $2.27 \pm 3.6$ \\
\cline { 2 - 5 } & Total & $5.75 \pm 5.4$ & $3.5 \pm 3.8$ & $6.12 \pm 6.5$ \\
\hline \multirow{2}{*}{ Anxiety } & State & $37.75 \pm 10.2$ & $35.72 \pm 7.7$ & $36.01 \pm 11.3$ \\
\cline { 2 - 5 } & Trait & $39.43 \pm 7.6$ & $37.27 \pm 6.8$ & $37.4 \pm 7.1$ \\
\hline \multirow{3}{*}{ Occupational burnout } & Emotional exhaustion & $16.33 \pm 7.3$ & $14.11 \pm 4.4$ & $14.78 \pm 6.3$ \\
\cline { 2 - 5 } & Depersonalization & $8.39 \pm 4.6$ & $6.66 \pm 2.3$ & $6.2 \pm 4.2$ \\
\cline { 2 - 5 } & $\begin{array}{c}\text { Reduced personal } \\
\text { accomplishment }\end{array}$ & $34.13 \pm 6.1$ & $31.5 \pm 3.7$ & $35.32 \pm 6.4$ \\
\hline
\end{tabular}

Table 4. Correlation between depression, state and trait anxiety, occupational burnout severity and the marital status

\begin{tabular}{|c|c|c|c|c|}
\hline \multirow{2}{*}{\multicolumn{2}{|c|}{$\begin{array}{l}\text { Studied factors of depression, state anxiety, trait anxiety, } \\
\text { and occupational burnout }\end{array}$}} & \multicolumn{2}{|c|}{ Average values for workers with different marital status } & \multirow{2}{*}{$\begin{array}{l}\text { Significant differences } \\
\text { (U-test) }\end{array}$} \\
\hline & & Married & Other status & \\
\hline \multicolumn{5}{|c|}{ Hospital №1 } \\
\hline \multirow{3}{*}{ Depression } & C-A & $4.28 \pm 4.0$ & $3.46 \pm 3.2$ & No \\
\hline & S-P & $1.56 \pm 1.5$ & $2.07 \pm 1.9$ & No \\
\hline & Total & $5.84 \pm 5.14$ & $5.53 \pm 5.0$ & No \\
\hline \multirow{2}{*}{ Anxiety } & State & $36.72 \pm 9.7$ & $37.9 \pm 10.6$ & No \\
\hline & Trait & $38.1 \pm 7.7$ & $40.4 \pm 7.8$ & No \\
\hline \multirow{3}{*}{ Occupational burnout } & Emotional exhaustion & $15.6 \pm 6.9$ & $16.6 \pm 7.9$ & No \\
\hline & Depersonalization & $8.64 \pm 4.5$ & $7.9 \pm 4.7$ & No \\
\hline & $\begin{array}{l}\text { Reduced personal } \\
\text { accomplishment }\end{array}$ & $34.2 \pm 6.2$ & $34.07 \pm 6.3$ & No \\
\hline \multicolumn{5}{|c|}{ Hospital № 2} \\
\hline \multirow{3}{*}{ Depression } & C-A & $1.9 \pm 1.4$ & $3.4 \pm 3.2$ & No \\
\hline & S-P & $1.07 \pm 1.4$ & $1.4 \pm 1.1$ & No \\
\hline & Total & $3.0 \pm 2.1$ & $4.8 \pm 4.5$ & No \\
\hline \multirow{2}{*}{ Anxiety } & State & $36.1 \pm 7.6$ & $34.6 \pm 8.7$ & No \\
\hline & Trait & $37.9 \pm 6.6$ & $35.6 \pm 7.7$ & No \\
\hline \multirow{3}{*}{ Occupational burnout } & Emotional exhaustion & $14.4 \pm 4.8$ & $13.2 \pm 3.5$ & No \\
\hline & Depersonalization & $6.7 \pm 2.0$ & $6.4 \pm 3.3$ & No \\
\hline & $\begin{array}{l}\text { Reduced personal } \\
\text { accomplishment }\end{array}$ & $31.6 \pm 4.1$ & $31.2 \pm 2.8$ & No \\
\hline \multicolumn{5}{|c|}{ Hospital № 3} \\
\hline \multirow{3}{*}{ Depression } & C-A & $4.8 \pm 3.2$ & $3.6 \pm 3.0$ & $U=303.0^{\star \star}$ \\
\hline & S-P & $2.2 \pm 2.0$ & $2.4 \pm 1.4$ & No \\
\hline & Total & $6.8 \pm 5.1$ & $5.9 \pm 4.5$ & No \\
\hline \multirow{2}{*}{ Anxiety } & State & $35.9 \pm 11.03$ & $37.03 \pm 11.64$ & No \\
\hline & Trait & $36.6 \pm 7.4$ & $38.3 \pm 7.02$ & No \\
\hline \multirow{3}{*}{ Occupational burnout } & Emotional exhaustion & $14.9 \pm 6.1$ & $15.5 \pm 6.2$ & No \\
\hline & Depersonalization & $6.5 \pm 3.4$ & $6.5 \pm 4.6$ & No \\
\hline & $\begin{array}{l}\text { Reduced personal } \\
\text { accomplishment }\end{array}$ & $36.4 \pm 5.3$ & $34.2 \pm 6.6$ & No \\
\hline
\end{tabular}

Note: ${ }^{*}$ — sigificant differences $(p \leq 0.01) ;{ }^{* \star}$ - significant differences $(p \leq 0.05)$. 
another locality to perform their professional duties during the pandemic. Emotional exhaustion as a factor of occupational burnout played a vital part in development of depressive symptoms in all the infectious hospitals employees. In hospitals № 1 and 2 employees, both state and trait anxiety increased with the growth of occupational burnout manifestations levels. It is noteworthy that in all subgroups of healthcare workers state anxiety increased with reduced personal accomplishment level growth. In other words, state anxiety is based on lack of motivation to work, negative evaluation of one's work and its results, as well as prospects in the profession in general (the specialist is convinced that he deserves the best), including dissatisfaction with duties and the desire to shift responsibility onto his (her) colleagues.

Management of psychological follow-up for medical staff working in infectious hospitals for COVID-19 patients

Since April 10, 2020 the psychological service (4 medical psychologists and 1 psychologist) of the Federal Siberian Research Clinical Center under FMBA of Russia and the branch of FSRCC FMBA of Russia, the Clinical Hospital № 42 in Zelenogorsk, was partially diverted to solution of urgent tasks related to psychological support of healthcare workers involved in care provision to patients with novel coronavirus infection. Psychopreventive and psychocorrectional actions were carried out on a phased basis.

The main tasks of the first phase (prior to opening of the first infectious hospital) were as follows: creating an enabling environment and reduction of tension between co-workers resulting primarily from uncertainty and unpredictability of the current situation. Provision of information was the main working method during that phase (filling the information gaps, provision of adequate information). The memo "How to overcome anxiety and stress during the pandemic staying at work" for healthcare workers was issued and published on the medical institution information portal. Further, the medical managers and appropriate staff were familiarized with recommendations on prevention of psychological ill-being in physicians and medical staff during the pandemic, as well as with recommendations on the target groups' psychological follow-up under the context of COVID-19 pandemic [3]. The managers were given access to recommendations on psychological follow-up of the medical institutions heads and heads of departments in the context of care provision to patients with COVID-19.

The second phase started immediately after opening the first infectious hospital, and it is an ongoing phase. The main task of that phase was to create the enabling environment for effective adaptation of employees to the infectious hospital working conditions, including prevention, timely diagnosis and correction of neurotic disorders and states. All employees were informed about goals and tasks of forthcoming work, as well as about its voluntary nature.

During that phase the psychodiagnostic assessment of anxiety and depression symptoms was carried out at least once every 14 days, and for sure within first three days after starting work in the hospital and at the final stage. The current psycho-emotional status of at-risk employees was monitored weekly in order to reveal the neurotic symptoms worsening. The availability of psychological assistance was ensured by a number of measures. The 24-hour hotline was created for individual counseling. For healthcare workers of the field hospital located in Eruda settlement of the Severo-Yeniseysky District the face-to-face counseling by medical psychologist was available.

Training aimed at team-building, soft skills improvement and learning how to use the self-help techniques (selfregulation, self-organization, relaxation, etc.) was carried out in groups two times a week using the remote technologies (video conferencing).

Considering the certain employees' unwillingness to join the psychological support activities and understanding the inefficiency (uselessness) of using the coercive measures in further work with the team, we invited all specialists involved in working with COVID-19 patients to join the psychological support chat, giving them an opportunity to familiarize

Table 5. Relationship between anxiety and depression symptoms severity, and occupational burnout factors in healthcare workers of infectious diseases hospitals

\begin{tabular}{|c|c|c|c|}
\hline \multirow{2}{*}{$\begin{array}{l}\text { Studied depression, state and trait } \\
\text { anxiety levels }\end{array}$} & \multicolumn{3}{|c|}{ Occupational burnout factors } \\
\hline & Emotional exhaustion & Depersonalization & $\begin{array}{l}\text { Reduced personal } \\
\text { accomplishment }\end{array}$ \\
\hline \multicolumn{4}{|c|}{ Hospital № $1(n=53)$} \\
\hline C-A & $0.285^{\star \star}$ & - & - \\
\hline S-P & $0.462^{*}$ & - & - \\
\hline Depression & $0.377^{\star}$ & - & - \\
\hline State anxiety & $0.570^{*}$ & $0.352^{*}$ & $-0.307^{* \star}$ \\
\hline Trait anxiety & $0.378^{*}$ & $0.367^{*}$ & - \\
\hline \multicolumn{4}{|c|}{ Hospital № $2(n=18)$} \\
\hline $\mathrm{C}-\mathrm{A}$ & - & - & - \\
\hline S-P & $0.563^{\star \star}$ & - & - \\
\hline Depression & $0.551^{\star \star}$ & - & - \\
\hline State anxiety & - & - & $-0.535^{\star \star}$ \\
\hline Trait anxiety & - & - & - \\
\hline \multicolumn{4}{|c|}{ Hospital № $3(n=55)$} \\
\hline $\mathrm{C}-\mathrm{A}$ & $0.375^{\star}$ & $0.333^{*}$ & $-0.263^{* \star}$ \\
\hline S-P & $0.381^{*}$ & - & $-0.375^{*}$ \\
\hline Depression & $0.405^{*}$ & $0.288^{\star \star}$ & $-0.320^{\star \star}$ \\
\hline State anxiety & $0.495^{\star}$ & $0.296^{\star \star}$ & $-0.475^{\star}$ \\
\hline Trait anxiety & $0.518^{\star}$ & - & $-0.365^{\star}$ \\
\hline
\end{tabular}

Note: * - significance level $p \leq 0.01 ;{ }^{* \star}-$ significance level $p \leq 0.05$ 
Table 6. ealthcare workers' involvement in psychological support activities during the pandemic

\begin{tabular}{|c|c|c|}
\hline & $\begin{array}{c}\text { Infectious hospitals in Federal Siberian Research } \\
\text { Clinical Center, Krashoyarsk, and Clinical Hospital № } \\
\text { 42, Zelenogorsk; Proportion of people, \% }\end{array}$ & $\begin{array}{c}\text { Field hospital deployed in the territory of } \\
\text { "Olimpiadinsky" Ore Mining and Processing } \\
\text { Enterprise, Eruda settlement, Severo-Yeniseysky } \\
\text { District, Krasnoyarsk Territory; } \\
\text { Proportion of people, \% }\end{array}$ \\
\hline $\begin{array}{l}\text { Number of healthcare workers invited to } \\
\text { participate in psychological support activities }\end{array}$ & $n=216$ & $n=68$ \\
\hline Format of work & Remote & Face-to-face \\
\hline \multicolumn{3}{|c|}{ Activities: } \\
\hline $\begin{array}{l}\text { Independent study of memos, guidelines and } \\
\text { other information materials }\end{array}$ & $92(42.5 \%)$ & $57(83.8 \%)$ \\
\hline Psychodiagnostic screening assessment & $171(79.1 \%)$ & $55(80.8 \%)$ \\
\hline $\begin{array}{l}\text { Individual counseling upon individual } \\
\text { appointment (including calling the hotline) }\end{array}$ & $4(1.85 \%)$ & $9(13.23 \%)$ \\
\hline Group training & $26(12.03 \%)$ & $0(0 \%)$ \\
\hline Psychological support chat & $74(34.2 \%)$ & $34(50 \%)$ \\
\hline "Psychological Thermometers" & $3(1.38 \%)$ & $1(1.47 \%)$ \\
\hline
\end{tabular}

themselves with informational materials and tasks on a regular basis. In particular, the healthcare workers were introduced to self-observation diaries with protocols of irrational thoughts (cognitive behavioural approach to modifying the dysfunctional beliefs), art therapy exercises for negative emotions management and psychoemotional stress relief after work, mindfulness-based writing practices (mindfulnessbased cognitive therapy), and audio and video files (sessions of autogenic training, instilled rest, meditation, etc.) for rapid psychophysiological resources recovery and current functional state optimization. Thus, joining the chat allowed one to become involved in the process, execute the tasks at his (her) own pace, but required no active participation (which was likely to be an additional source of stress for some workers).

During that phase all employees were invited to join the "Psychological Thermometers" project of FMBA of Russia for physicians, mid-level practitioners and nursing staff developed in conjunction with the Faculty of Psychology of Lomonosov Moscow State University. The employees could use three "psychological thermometers" to measure their "emotional themperature" online and receive the immediate supportive feedback concerning the self-help measures, collegues' support and the need to call for professional psychological assistance. Self-examination was performed using no authentification, but the employee was allowed to submit the contact information requesting the targeted professional psychological assistance.

The total of 284 healthcare workers was invited to participate in the psychological support activities. The activities were carried out remotely in all hospitals, except the field hospital located in the territory of "Olimpiadinsky" Ore Mining and Processing Enterprise in the Eruda settlement of Severo-Yeniseysky District of the Krasnoyarsk Territory. The medical psychologist was sent to the field hospital as a part of the integrated team of specialists. The statistics of healthcare workers' participation in the psychological support activities is presented in Table 6.

The table demonstrates that higher degree of staff involvement is observed in the infectious diseases hospital providing face-to-face counseling. In our opinion, this is due to the fact that after the medical psychologist recruitment the direct participation in the meetings and planning conferences becomes possible. Thereby, the specialist may give more detailed information about goals and tasks of psychological support to colleagues during conversation, establish personal relationship, create the safe communication environment, answer the questions and to some extent overcome the psychological resistance during the initial contact.

\section{CONCLUSION}

In general, analysis of psychological support activities for healthcare specialists working in the infectious diseases hospitals for patients with coronavirus infection indicated that despite the prevalence of alarming and depression symptoms the willingness of employees to participate in the psychodignosic testing, individual counseling, training, etc., remained low. The conflict between the objective need (according to psychodignosic assessment results) and the professional psychological assistance availability on one hand, and the unwillingness to accept the assistance on the other hand, is obvious.

This fact does not conflict with the foreign colleagues' observations. Among others, the healthcare workers in some regions of China also refused to participate in the individual and group psychotherapy sessions and never requested psychological assistance despite the signs of irritability and high level of psychological distress [9]. The discovered phenomenon requires further detailed study. However, it is already clear that the modern medical worker's ability to understand his (her) psychological deficits while experiencing distress, to take timely measures in order to stabilize his (her) psycho-emotional state (self-help skills, calling the appropriate specialist) and activate the resources needed for effective health-preserving coping, is the essential component of professional competence. In our opinion, the development of such competence is important not only for adequate working tasks solution under the context of high professional risk, but also for effective professionalization of a specialist starting from the moment of study at a medical educational institution.

In view of the above, it would be better to discuss the need for the third phase of the healthcare workers psychological followup (after finishing working in the infectious diseases hospitals for patients with COVID-19). Together with psychophysiological rehabilitation, prevention of post-traumatic stress disorder, etc., the creation of environment for discussed professional competence development will become one of the main tasks of the third phase. 


\section{References}

1. Водопьянова Н. Е. Синдром выгорания. Диагностика и профилактика: практическое пособие // ЭБС Юрайт [сайт]. URL: https://urait.ru/bcode/402432 (дата обращения: 07.07.2020).

2. Полшкова Т. А. Проблема ситуативной тревожности в психолого-педагогических исследованиях // Актуальные вопросы современной психологии : материалы II Междунар. науч. конф. (г. Челябинск, февраль 2013 г.). 2013. С. 107-110.

3. ФМБА России создало службу психологической помощи на базе Федеральных медицинских центров, перепрофилированных под прием больных COVID-19 [Офиц. сайт]. URL: http://fmbaros.ru/press-tsentr/novosti/ detail/?ELEMENT_ID=38735 (дата обращения 12.05.2020)

4. Gold J.A. Covid-19: adverse mental health outcomes for healthcare workers // British Medical Journal. 2020. P. 369

5. Abdulkarim A.R., Temsah M.H., Ayman A. A. etal. Middle East Respiratory Syndrome-Corona Virus (MERS-CoV) associated stress among medical students at a university teaching hospital in Saudi Arabia // Journal of Infection and Public Health. 2020. № 5. P. 687-691.

6. Alsubaie S., Hani Temsah M., Al-Eyadhy etal. Middle East Respiratory Syndrome Coronavirus epidemic impact on healthcare workers' risk perceptions, work and personal lives // Journal of Infection in Developing Countries. 2019. P. 920-926.

\section{Литература}

1. Водопьянова Н. Е. Синдром выгорания. Диагностика и профилактика: практическое пособие // ЭБС Юрайт [сайт]. URL: https://urait.ru/bcode/402432 (дата обращения: 07.07.2020)

2. Полшкова Т. А. Проблема ситуативной тревожности в психолого-педагогических исследованиях // Актуальные вопросы современной психологии : материалы II Междунар. науч. конф. (г. Челябинск, февраль 2013 г.). 2013. С. 107-110.

3. ФМБА России создало службу психологической помощи на базе Федеральных медицинских центров, перепрофилированных под прием больных COVID-19 [Офиц. сайт]. URL: http://fmbaros.ru/press-tsentr/novosti/ detail/?ELEMENT_ID=38735 (дата обращения 12.05.2020)

4. Gold J.A. Covid-19: adverse mental health outcomes for healthcare workers // British Medical Journal. 2020. P. 369.

5. Abdulkarim A.R., Temsah M.H., Ayman A. A. etal. Middle East Respiratory Syndrome-Corona Virus (MERS-CoV) associated stress among medical students at a university teaching hospital in Saudi Arabia // Journal of Infection and Public Health. 2020. № 5. P. 687-691.

6. Alsubaie S., Hani Temsah M., Al-Eyadhy etal. Middle East Respiratory Syndrome Coronavirus epidemic impact on healthcare workers' risk perceptions, work and personal lives // Journal of Infection in Developing Countries. 2019. P. 920-926.
7. Amaratunga C.A., O'Sullivan T.L., Phillips K.P. etal. Ready, aye ready? Support mechanisms for healthcare workers in emergency planning: a critical gap analysis of three hospital emergency plans // American journal of disaster medicine. 2007. № 4. P. 195-210.

8. Bao Y., Sun Y., Meng S. etal. 2019-nCoV epidemic: address mental health care to empower society // The Lancet. 2020. № 10224. P. 37-38.

9. Chen Q., Liang M., Li Y. etal. Mental health care for medical staff in China during the COVID-19 outbreak // The Lancet Psychiatry. 2020. № 4. P. 15-16.

10. Dai Y., Hu G., Xiong H. etal. Psychological impact of the coronavirus disease 2019 (COVID-19) outbreak on healthcare workers in China // MedRxiv. 2020.

11. Gebrie M.H. An Analysis of Beck Depression Inventory 2nd Edition (BDI-II) // Global Journal of Endocrinological Metabolism. 2018. P. $1-5$

12. Greenberg N., Docherty M., Gnanapragasam, S. Managing mental health challenges faced by healthcare workers during covid-19 pandemic / / British Medical Journal. 2020. P. 368.

13. Y Ni M., Yang L., Leung C., etal. Mental Health, Risk Factors, and Social Media Use During the COVID-19 Epidemic and Cordon Sanitaire Among the Community and Health Professionals in Wuhan, China: Cross-Sectional Survey // JMIR Mental Health. 2020. № 5 .

7. Amaratunga C.A., O'Sullivan T.L., Phillips K.P. etal. Ready, aye ready? Support mechanisms for healthcare workers in emergency planning: a critical gap analysis of three hospital emergency plans // American journal of disaster medicine. 2007. № 4. P. 195-210.

8. Bao Y., Sun Y., Meng S. etal. 2019-nCoV epidemic: address mental health care to empower society // The Lancet. 2020. № 10224. P. 37-38.

9. Chen Q., Liang M., Li Y. etal. Mental health care for medical staff in China during the COVID-19 outbreak // The Lancet Psychiatry. 2020. № 4. P. 15-16.

10. Dai Y., Hu G., Xiong H. etal. Psychological impact of the coronavirus disease 2019 (COVID-19) outbreak on healthcare workers in China // MedRxiv. 2020.

11. Gebrie M.H. An Analysis of Beck Depression Inventory 2nd Edition (BDI-II) // Global Journal of Endocrinological Metabolism. 2018. P. 1-5.

12. Greenberg N., Docherty M., Gnanapragasam, S. Managing mental health challenges faced by healthcare workers during covid-19 pandemic / / British Medical Journal. 2020. P. 368.

13. Y Ni M., Yang L., Leung C., etal. Mental Health, Risk Factors, and Social Media Use During the COVID-19 Epidemic and Cordon Sanitaire Among the Community and Health Professionals in Wuhan, China: Cross-Sectional Survey // JMIR Mental Health. 2020. № 5. 